\title{
THE TERM PRECEPTOR: ITS INTERPRETATION IN SOUTH AFRICAN NURSING COLLEGES AND INTERNATIONAL NURSING LITERATURE
}

\author{
H.I.L. Brink
}

\begin{abstract}
The purpose of this study was two-fold, namely: 1) to obtain clarity on the meaning of the term preceptor, and 2) to establish how the term preceptor is interpreted in the nursing colleges of the $R S A$ and to ascertain whether this interpretation is consistent with the general connotation of the term in contemporary nursing literature. Dictionaries and relevant contemporary nursing literature formed the unit of analysis for obtaining clarity on the meaning of the term preceptor, while the unit of analysis for the second section of the study comprised responses of nursing college principals to a questionnaire.

The data obtained in the investigation indicate that the term has acquired a specific connotation within the
\end{abstract}

international nursing context and that specific defined attributes distinguishes it from the broad and general definition found in standard dictionaries. Within the South African nursing context the term preceptor has not yet acquired a specific connotation, but appears to mean different things to different people.

\section{Opsomming}

Die doel van hierdie studie was tweeledig, naamlik I) om duidelikheid omtrent die betekenis van die term preseptor te verkry, en 2) om vas te stel hoe die term preseptor in SuidAfrikaanse verpleegkolleges geinterpreteer word en of hierdie interpretasie ooreenstem met die algemene

konnotasie van die term in eietydse verpleegliteratuur. Woordeboeke en toepaslike eietydse verpleegliteratuur was die spesifieke eenhede van ontleding wat bestudeer is om meer duidelikheid omtrent die betekenis van die term preseptor te verkry, terwyl die responsies van verpleegskoolprinsipales op ' $n$ vraelys as ontledingseenheid vir die tweede gedeelte van die studie gebruik is.

Bevindinge dui aan dat die term preseptor 'n spesifieke konnotasie binne die internasionale verpleegkonteks verkry het, wat wel verskil van die algemene en breë definisie soos in standaard woordeboeke aangedui. Binne die Suid-Afrikaanse verpleegkonteks het die woord egter nog nie 'n spesifieke konnotasie verkry nie.

\section{INTRODUCTION}

The major focus of this study is centered on the task of clarifying the term preceptor as used within the nursing context. Until quite recently this term was not common in the vocabulary of South African nurses. Searle and Mellish had occasionally used it in their writings. Since 1975 the Unisa nursing lecturers used it to refer to the group of experienced registered nurses in the health services who assisted with the supervision of a proportion of Unisa nursing students practica in the clinical field. Other than the above the term preceptor was seldom used within the nursing context in this country. However, in international nursing literature reference was made to preceptors with increasing frequency from the late 1970s onwards.

With the re-organisation of nursing education in South Africa into the system of tertiary education during the early 1980s several Nursing Colleges implemented the use of preceptorship experiences for their students. Consequently the term preceptor was heard more commonly in nursing conversations. However, it appeared to lack clear and concise definition and the impression was gained that it meant different things to different people and that considerable confusion surrounded the term. Collingwood (1938:2) stated that when a term is common in usage and confusing in meaning, it is not possible to decide privately when to apply and when to refuse it, nor is it helpful to continue its use without clarification. It is furthermore generally accepted that misunderstanding, bad theory and practice can result when words in use are inadequately explored and understood. One cannot achieve an accurate exchange of views and read a meeting of the minds unless one is talking the same language.

A need was therefore recognised to obtain clarity on what the term preceptor meant to all who were involved in implementing preceptorship and whether it meant the same to all. There was also a need for comparison of the local interpretation of the term with its use in the international nursing literature. Clarification of terminology is important because for example, should ambiguities and inconsistencies be found in its interpretation these could be cleared, misunderstanding could be corrected and communication improved among all those using the term.

\section{PURPOSE OF THE STUDY}

The purpose of the study was two-fold, namely 1) to obtain clarity on the meanin of the term preceptor and 2) to establish how the term preceptor is interpreted in the Nursing Colleges of the RSA and to ascertain whether this interpretation is consistent with the general connotation of the term in contemporary nursing literature.

\section{RESEARCH QUESTIONS}

The following research questions provided direction to the study.

What is the common usage of the term preceptor as defined in a standard dictionary?

What is the general connotation of the term preceptor in contemporary nursing literature?

Does the common usage of the term preceptor as defined in the dictionary differ from its use in the nursing literature?

What is the meaning of the term preceptor according to its interpretation in nursing colleges in the RSA?

Are there differences in the interpretation of the term preceptor among nursing colleges in the RSA? 
Do nursing colleges attach a different general connotation to the term preceptor than is done in contemporary nursing literature?

\section{THE RESEARCH DESIGN}

In carrying out this investigation a descriptive research design was utilised, projecting a flow of enquiry through the following procedures:

- describing the meaning of the term preceptor by means of

* examination of common usage as defined in dictionaries.

* systematic examination of usage within the nursing context as described in contemporary nursing literature.

- describing the meaning of the term preceptor as interpreted in nursing colleges by means of

* an analysis of the responses obtained from college principals on a questionnaire specifically designed for the purpose.

Dictionaries and relevant contemporary nursing literature formed the unit of analysis for the first section of the study, while the unit of analysis for the second section of the study comprised responses of nursing college principals. A convenience sample of dictionaries and relevant nursing literature was selected, while a questionnaire was sent to the principal of each nursing college recognised as such by the South African Nursing Council (SANC) during 1987. A computer list containing the names and addresses of each one of these colleges $(n=27)$ had been obtained from the SANC.

Principals were informed of the objectives of the study and were assured that the information given would not be linked to their names and colleges and that anonymity would be respected. A response would be regarded as consent for the information to be used in the study.

The questionnaire used to obtain ormation from the nursing college principals on how the term preceptor was used and interpreted in their colleges was self-designed. An interview would probably have been more effective in meeting the purpose of the study, as it would have permitted in depth probing. The latter method was however considered impractical and cost ineffective for this particular study as nursing colleges are widely dispersed across the whole country. The questionnaire consisted of eleven questions of which five were open-ended and six required respondents to choose one of a number of alternative responses. The questions were straightforward and attempted to elicit from the respondents:what the term preceptor means to them; whom they believed should act as a preceptor; who the preceptor should be responsible to; whether preceptors should be specially appointed; areas in which preceptors were functioning; what the main functions and responsibilities of preceptors were; whether the terms preceptor and clinical instructor were regarded as synonyms; what the major differences in function were between clinical instructors and preceptors; if they were considered to be different categories and whether specific preceptors had been appointed in their particular educational system.

\section{FINDINGS}

Common usage of the term preceptor as defined in dictionaries

According to the Oxford English Dictionary (1933:1649) the term preceptor was originally introduced in the English language in 1440 as a synonym for teacher, tutor or instructor. It is still defined as such in all of the standard dictionaries which were consulted (Blackies Standard Shilling Dictionary 1914; The Readers Digest Great Encyclopaedic Dictionary 1964; The New Collins English Dictionary 1984 and The Readers Digest Universal Dictionary 1987). Webster, in both available editions of his New International Dictionary $(1953 ; 1961)$. includes the common definition of tutor, teacher and instructor but also presents additional and more specific definitions, namely " $A$ practising physician who takes an undergraduate medical student and gives him personal training in the practice of medicine." (1953:1943; 1961:1784); and "A specialist in a branch of medicine or surgery who takes a young physician as a resident student and gives him personal training in his specialty - for example obstetrics and gynaecology." (1961:1784)

From the latter definitions it is clear that the term preceptor has both a general and a specific connotation and that the specific connotation is context bound. It can thus be inferred that the meaning of the term should always be examined within the context in which it is used. According to Webster's definition the specific connotation of the term preceptor appears to have been acquired within the medical context. This suggests that the word was already well established in the medical vocabulary before the 1950's.

\section{USE OF THE TERM PRECEPTOR IN CONTEMPORARY NURSING \\ LITERATURE \\ Historical development}

From reports in the nursing literature it appears that the term preceptor was adopted in the nursing vocabulary in the U.S.A. when nurse practitioner programmes were introduced during the early 1960's. Physician preceptors were coopted to give registered nurses personal training in the skills required of nurses in expanded roles (Monnig 1983:39; Myrick 1988:589). As the nurse practitioner role became more accepted, but few nurse practitioners were specifically prepared to teach in such programmes, a variety of continuing education programmes were developed to enable nurse practitioners to acquire the necessary knowledge and skill to teach in practitioner programmes. Nurse practitioner clinical preceptors began to replace physician preceptors in the nursing programmes (Brykczynski 1985:82).
Since this time the concept of preceptorship is said to have acquired and continues to gain increasing impetus as a method of clinical teaching in nursing (Helmuth and Guberski 1980:36-39). In 1975 the term preceptorship appeared for the first time as a classification in the International Nursing Index (Shamian and Inhaber 1985:79). By this time a total of 58 preceptorship programmes were reported for nursing students in the United States. By 1985 the number had escalated to 109 (Spears 1986:4). Also in Canada several university and community college schools of nursing were adopting preceptorship programmes as a method for the clinical teaching of their students (Myrick 1988:136). Preceptors were found in a variety of health service settings - general nursing units, ambulatory units and critical care units, to name but three (Shamian and Inhaber 1985:89). The term preceptor had acquired a specific connotation within the nursing context similar to Webster's New International Dictionary definition pertaining to the medical practitioner, but adapted and modified within the nursing context. It was not used in the broad sense as defined in standard dictionaries as a synonym for teacher or instructor, therefore it did not serve as merely an alternative name for any of the many categories of nurses engaged in teaching. Specific defined attributes distinguished the use of the term preceptor from other teaching categories.

\section{WHAT ARE THE DEFINED OR CRITICAL ATTRIBUTES OF PRECEPTOR?}

Even though there are certain variations reported in the international nursing literature with regard to purpose, role, selection and preparation of preceptors there appears to be general consensus that the term preceptor refers to a person who meets the following criteria:

- is service or unit based in other words, one who functions in a clinical setting (for example, as a clinical supervisor of a unit, ward sister or even another health practitioner) and is seen as a valued member of the staff;

- possesses clinical competence and expertise in her area of practice, has a good conceptual base of nursing, is prepared for teaching and shows interest in student education;

- is specially selected or appointed to work for nurse learners and is allowed time for this in addition to her regular duties;

- serves as a role model and resource person for nurse learners through $a$ one-to-one relationship in a carefully planned and structured system of learning (Goldenberg 1986:11; Reilly and Oerman 1985:137; Shamian and Inhaber 1985:79; Turnbull 1983:10).

\section{WHAT ARE THE FUNCTIONS AND RESPONSIBILITIES OF THE PRECEPTOR?}

The responsibilities of the preceptor as described in the literature are multiple and 
varied and may differ slightly from one situation to the next. Assigned responsibilities depend to a large extent on which and how many other categories of nurse teachers are involved in the clinical teaching of the student and the definition of the specific responsibilities of each one of these categories. Limon Bargagliotti and Spencer (1982:17) and Reilly and Oerman (1985:138) draw attention to the importance of a written description that spells out the roles and responsibilities of the preceptors, tutors and clinical instructors particularly in relation to the selection of learning experiences, instruction in the setting, supervision and evaluation of learning. Nevertheless despite the variations in responsibility certain common responsibilities of preceptors could be identified. All preceptors described in the available literature function as teachers, resource persons and role models in the clinical setting. The preceptor is a realistic role model because she is part of the clinical setting (Dobbie and Karlinsky 1982:40). There are two primary responsibilities mentioned in most reports, namely: 1) orientation of preceptees to the unit and to their work role and 2) socialisation of preceptees within the unit (Chickerella and Lutz. 1981; Crancer et al. 1975; Everson et al. 1981; Friesen and Conohan 1980; Knauss 1980; Haes 1983; May 1980; McGrath and Koewing 1978; Murphy and Hammerstad 1981; Patton et al. 1981; Walters 1981). Other responsibilities mentioned are programme planning, assisting in the establishment of objectives and priorities, evaluating, as well as communicating with superiors regarding the prugress of preceptees (Dobbie and Karlinsky 1982; Shamian and Inhaber 1985). The role of the preceptor is said to decrease as the preceptee takes on more and more responsibility. The responsibility is both complementary and changing: as the student or orientee becomes more comfortable in the unit's function, the preceptor steps back as teacher and assumes the role of resource person and/or facilator (Shamian and Inhaber 1985:82). Preceptors in general are expected to fulfill their roles in mutual negotiation with the student and the tutor responsible for teaching the theory for that particular practica, and do not function as formal teachers per se (McGrath and Princeton 1987: 133).

\section{SELECTION OF PRECEPTORS}

There is no absolute agreement in the literature as to who should select the preceptor. The selection may be carried out by nursing management of the hospital (Crancer et al. 1975; Knauss 1980; Walters 1981), by educators from the teaching setting (Everson et al. 1981; Patton et al. 1981) or jointly (Crancer et al. 1975; Friesen and Conahon 1980; Reilly and Oerman 1985).

\section{PRECEPTORS VERSUS OTHER NURSE CATEGORIES}

On considering the defining attributes and responsibilities of a preceptor it should have become clear that preceptor is not an alternative name for college tutor, clinical instructor, ward sister or mentor. When the nursing college tutor or the lecturer from the university nursing department carries out her teaching responsibilities in the clinical situation she does so as a tutor or lecturer and not as a preceptor. She is not part of the service or unit and with a few exceptions not necessarily experienced or clinically expert in the clinical setting in which she teaches. Hence she does not qualify to be called a preceptor. The clinical instructor is also not necessarily a preceptor even though she may be serviced based. Unless she is assigned to one specific practice area in which she is experienced and highly competent, practises in and confines her clinical instruction to that particular area, functions in a one-to-one relationship with students on a daily basis and meets the other criteria specified for a preceptor, she is not a preceptor. As a rule the clinical instructor covers not only one particular clinical area, but covers a number of clinical areas and is mainly responsible for demonstrations. She seldom finds time to enter into a one-to-one relationship as the clinical instructor-student ratio may be as high as 1:50. She seldom serves as a role model with regard to interactions with staff members, community members and family of patients or decision-making in the practice situation. She does not actively practise nursing -- her responsibilities are confined to instruction. The ward sister is the most likely person to function as preceptor but does not automatically become a preceptor on appointment as a ward sister. She has to meet the required criteria for a preceptor and be specifically assigned to this function.

A mentor is not the same as a preceptor. Preceptors provide an opportunity for the development of a mentor relationship; however, not all preceptors necessarily become mentors (Ruetz 1987; Reilly and Oerman 1985). Deane and Campbell (1985:144) draw attention to the following differences between the concepts preceptor and mentor:

- There is no free choice involved in the preceptor-preceptee relationship whereas there is such a choice in the mentor-protegé relationship. The preceptee or student is assigned to a specific preceptor while either the mentor or protegé can initiate the mentor relationship.

- The preceptor and preceptee work in the same setting within a structured set of expectations and their relationship is limited to a specific period of time. The relationship ends when the preceptee moves to another practice area or unit. The mentor and protege need not work in the same setting. Learning experiences are unstructured, expectations are not formally stated, but there is usually a long term relationship.

- Mentors are likely to enhance career planning, advancement and satisfaction. Rather than supervision they provide guidance, support and advice on personal and professional matters to help the protegé meet the demands of her course or career.

\section{INTERPRETATION OF THE TERM PRECEPTOR AT SOUTH AFRICAN NURSING COLLEGES}

Twenty-three of the 27 questionnaires

$(85,2 \%)$ which had been sent to the nursing college principals were returned. However, one of the questionnaires was returned unanswered with a note that the term preceptor was unknown to all members of the staff of that particular nursing college.

The responses to the remaining 22 questionnaires $(81,5 \%)$ were analysed by hand and are presented below question by question.

The responses to question I "What does the term preceptor convey to you? Please describe in your own words", are presented in Table 1 .

TABLE 1
Interpretation of the term preceptor by respondents
(n $=$ 22)
Interpretation (of word preceptor)
A teacher or instructor
A mentor and role model
A facilitator of learning
A registered nurse based in the clinical
area, who acts as a liaison person
with the college in arranging clinical
learning experiences
A registered nurse who is on the
payroll of the hospital and to whom
the responsibility to carry out clinical
instruction in the particular unit in
which she functions is allocated
A professional nurse who liaises between
the college and an affiliated hospital
A person giving practical training
A registered nurse in the practical
situation
A clinical teacher, instructor and
accompanier in clinical professional
practice
A person who makes available the
necessary clinical facilities

The data depicted in Table 1 suggests that the term preceptor has not yet acquired a specific connotation within the South African nursing context and that there is very little agreement among the respondents with regard to its meaning. With the exception of two interpretations, the meanings attached to the term were generally broad and vague. Almost onehalf of the respondents used the broad general meaning as defined in standard dictionaries, while one-third linked the meaning to the clinical situation, but not specifically.

Table 2 presents the responses to question 2 in which respondents were asked to indicate who, in their opinion, should act as a preceptor in nurse training programmes. Here, too, many different opinions were received, which further strengthened the inference made previously that very little clarity exists with regard to the meaning of the term preceptor and the 
TABLE 2

Respondents' views on who should act as a preceptor in nurse training programmes ( $n=22$ )

Who should act as preceptor? Number of responses

Tutors

Department or ward sisters

All registered nurses

Matrons, doctors, tutors, clinical instructors and ward sisters

A service based clinical spccialist or expert

Any professional nurse who has additional qualifications in nursing education and nursing administration

Any senior person

A registered nurse working in the ward but not in charge

A person who is competent in a specific clinical area and possesses teaching skills

Zone nursing manager or a member from the college clinical department

Clinical instructor

The principal or student counsellor

functioning of preceptors within the South

African nursing context.

With regard to question 3 "Should preceptors be directly responsible to the principal of the college?", ten (10) respondents replied in the negative, eight (8) in the affirmative, one was undecided and three (3) stated that it depended on who the preceptor was, for example, if she was a matron she should not be, but if she was a clinical instructor she should be.

In response to question four (4) "Should preceptors be specially appointed or selected?", twelve (12) respondents indicated that they should, while ten (10) were of the opinion that this should not be the case. Of the latter group, seven (7) indicated that teaching was an established function of every ward sister and no additional persons were needed to fulfil this function. One (1) respondent indicated

at by appointing a preceptor the itiative and responsibility of the ward sisters would be stifled. Another respondent did not regard preceptors as formal teachers and hence saw no reason for them to be appointed or selected.

More than one-half of the respondents (12) refrained from answering question 5 "Who should appoint preceptors?". There was little agreement on this point among the ten $(10)$ respondents who did respond. The following answers were obtained: both the principal and matron (3); the principal (2); the selection committee of the college council (2); college personnel (1); hospital personnel (1) and senior staff (1).

With the exception of one respondent there was general consensus in the answers to question 6 . The respondents believed that preceptors were active in the main areas of nursing, namely general, community health and psychiatry and midwifery. The one exception indicated that preceptors were active only in the fields of general nursing and midwifery.

In response to question 7 relating to the functions and responsibilities of the preceptors, answers varied considerably.
Seven respondents limited their responses to three functions. One respondent listed fourteen functions. The latter were however all very non-specific. The data obtained are displayed in Table 3.

\section{TABLE 3}

Functions and responsibilities of preceptors as described by respondents $(n=22)$

\section{Functions and responsibilities of}

preceptors

Number

Accompanies students

Assists with correlation of theory and practice

Assists in teaching

Assists in evaluating students

Organises learning experiences

Ensures that teaching resources are available

Teaches in the clinical situation

Acts as a role model

Assists students in training their clinical objectives

Socialises students

Counsels students

Follows up students in unit

Designs measurement instruments

Participates in O.S.C.E

Does research

Assists health unit manager

Liaises with college and hospital personnel

Develops curriculum

Interprets curriculum to service personnel

Creates a teaching-learning climate

Provides inservice education

8

7

7

7

6

5

2

2

2

1

1

1

I

Slightly more respondents (12) differentiated between preceptors and clinical tutors than those who did not (10). Of the latter group, four indicated that they did not use the term preceptor at all within their nursing context.

Question 9 "What is the major difference in the functions of the preceptor versus the clinical instructor?", was applicable to the twelve respondents who had indicated in question 8 that they did differentiate between preceptors and clinical tutors. Only eleven respondents answered the question and a variety of answers were received. These are depicted in Table 4 below.

In response to question 10 "Have specific preceptors been appointed in the service with which you are concerned?", seven respondents answered in the affirmative, while fourteen said they had not and one was uncertain.

The final question, "Do you think it is essential to use preceptors in the clinical situation?", was answered with a "yes" by eighteen respondents, while four replied "no". The latter all commented that ward teaching was a function of the ward sister and that it was quite unnecessary to appoint another category for this fuction.

\section{DISCUSSION OF FINDINGS}

From the results of the findings it can be deducted that even though the majority of respondents were in agreement that preceptors should be used in the clinical situation, the term preceptor has not yet acquired a specific connotation in the South African nursing context and preceptorship has not yet gained acceptance in the majority of nursing education programmes in this country. At not even one-third (7) of the participating nursing colleges had the use of preceptorship experiences for students been implemented. Among the colleges using preceptors there does not appear to be a shared common interpretation with regard to the term preceptor. Differences exist with regard to who should act as preceptor, what her functions and responsibilities are and how she can be distinguished from the clinical instructor. In fact it appears as though considerable confusion surrounds the term. In many instances the term is used in a broad and general manner as defined in standard dictionaries. Furthermore, the responsibilities and functions ascribed to the preceptor are not specific or circumscribed but general and broad. This makes it very difficult for an outsider to obtain a clear impression of who and what the preceptor is

The argument presented by more than one-third of the respondents who were against appointing or selecting preceptors was "Why change the status quo? Teaching was and is the function of every ward sister and no additional category is needed to take over this function". The practical implications of maintaining the status quo is, of course, a moot point. For several decades the nursing literature has been replete with the shortcomings of this system. Although it is generally accepted that teaching is vital at the ward sister's level and therefore one of her primary responsibilities, research has suggested that the teaching in the wards by ward sisters appears in many cases to be inadequate
TABLE 4

\begin{tabular}{|c|c|c|}
\hline Preceptor & Clinical instructor & Number \\
\hline Is allocated to a specific unit & Moves around from unit to unit & 3 \\
\hline Role is informal & Role is formal & 2 \\
\hline Is a companion & Is an instructor of practice & 2 \\
\hline Is a facilitator & Is an instructor of practice & 1 \\
\hline $\begin{array}{l}\text { Is synonymous to tutor and committed to } \\
\text { teaching }\end{array}$ & $\begin{array}{l}\text { Is committed to practical demonstration } \\
\text { and supervision }\end{array}$ & 1 \\
\hline Is responsible for quality patient care & Is responsible for education of the student & 1 \\
\hline Is a clinical expert in a particular field & Is a generalist & 1 \\
\hline
\end{tabular}


(Lelean 1973); that ward sisters are negating their educational functions and are not fulfilling their role of teacher, resource person and team leader (Brownlee 1983); that ward teaching often ends up being unplanned and ad hoc with little relevance to the total curriculuri (Alexander 1983); that ward teaching is incidental and educational needs of students are subordinate to nursing needs of patients (Myrick 1988); and that student nurses work mainly without adequate supervision and guidance and their clinical experience lacks any systematic attempt at the teaching of clinical competence

(Bradshaw 1989).

Several researchers have confirmed a relationship between workload, attitudes and leadership style of ward sisters and learning activities in the ward (Fretwell 1982; Ogier 1982; Orton 1981). In the light of these findings the necessity for innovation or alternative solutions is obvious. Preceptorship is one alternative that has been advocated and which, according to the international nursing literature, appears promising. Successful preceptorships contribute to quality patient care as well as quality student education. They facilitate collaboration between service and education (Turnbull 1983). Perhaps more clarity on the meaning of the term would promote a more positive attitude toward preceptorship.

\section{CONCLUSION AND}

\section{RECOMMENDATION}

The data obtained in the investigation suggest that the term has acquired a specific connotation within the international nursing context and that specific defined attributes distinguishes it from the broad and general definition found in standard dictionaries. Within the South African nursing context the term preceptor has not yet acquired a specific connotation. The term appears to lack clear and concise definition and means different things to different people. No group consensus on the meaning of the term appeared to exist. The presupposition which prompted this investigation was thus confirmed. There appears to be a lack of exposure to international nursing literature as only one person adopted the specific connotation described in the literature.

It is recommended that nurse educators be urged to adopt the specific interpretation of the term preceptor as used in the international nursing literature - this should eliminate confusion. It is further recommended that more attention be paid to specific definitions and clarity of meaning before adopting a term for common usage and that provision be made for college personnel to have reasonable access to international nursing literature and be encouraged to use it.

\section{LIST OF SOURCES}

Alex ander, M. 1983. Learning to nurse, integrating theory and practice. Edinburgh: Churchill Livingstone.

Backenstone, A.G. 1983. The use of clinical perceptors. In Preceptorship in nursing education, edited by Stuart-Siddal, $\mathrm{S}$ and Haberlin. Rockville, Maryland: Aspens Systems Corporation.

Bradshaw, P.L. 1989. Teaching and assessing in clinical nursing practice. New York: Prentice Hall.

Brownlee, E.B.I. 1983. The sisters-in-charge of hospital wards. An appraisal. Pretoria: University of South Africa.

Chickerella, B.G., Lutz, W.J. 1981. Professional nurturance: preceptorship for undergraduate nursing. In American Journal of Nursing. 81 (1) 107-109.

Collingwood, R.G. 1938. The principles of art. Oxford: Clarendon Press.

Deane, D., Campbell, J. 1985. Developing professional effectiveness in nursing. Reston, Virginia: Prentice-Hall.

Dell, M.B., Griffith, E. 1977. A preceptor program for nurses' clinical orientation. In Journal of Nursing Administration, 7(1), 30-38.

Dobie, B.J., Kowlinsky, N. 1982. A self-directed clinical practicum. In Journal of Nursing Education, 21(9), 39-4I.

Everson, S., Panoe, K., Pratt, P., King. A.M. 1981. Precepting as an entry model for newlyhired staff. In Journal of Continuing Education in Nursing, 12(1), 12-16.

Fretwell, J.E. 1982. Ward teaching and learning London: Royal College of Nursing.

Friesen, L., Conahan, B.J. 1980. A clinical preceptor program: Strategy for new graduate orientation. Journal of Nursing Administration, 10(4), 18-23.

Goldenberg, D. 1987/88. Preceptorship: A oneto-one relationship with a triple " $P$ " rating. (Preceptor, preceptee, patient). Nursing Forum, 23(1), 10-15.

Helmuth, M.R., Guberski, T.D. 1980 Preparation for preceptor role. Nursing Outlook, 28(1), 36-39.

Itano, J., Warren, J., Isida, D. 1987. A comparison of role conception and role deprivation of baccalaureate students in nursing participating in a preceptorship or a traditional clinical program. Journal of Nursing Education, 26(2), 69-73.

Knauss, P.J. 1980. Staff nurse preceptorship: an experiment for graduate nurse orientation. Journal of Continuing Education in Nursing, 11(1), 44-46.

Lelean, S.R. 1973. Ready for report nurse? $A$ study of communication in hospital wards. London: Royal College of Nursing.

Lewis, K.E. 1986. What it takes to be a preceptor. The Canadian Nurse, 82(11), 18-19.

Limon, S., Bargagliotti, L.A., Spencer, J. 1982. Providing preceptors for nursing students. What questions should you ask? Journal of Nursing Administration, 12(6), 16-19.

Maes, J. 1983. The challenge of being a preceptor. In Preceptorship in Nursing Education, edited by Stuart-Siddels and Haberlin. Rockville, Maryland: Aspens Systems Corporation.

May, L. 1980. Clinical preceptors for new nurses. American Journal of Nursing, 80 (10), 1824-1826.

McGrath, B.J., Koewing, J.F. 1978. A clinical preceptorship for new graduate nurses. Journal of Nursing Administration, 8(3), 12-18.

McGrath, B.J., Princeton, J.C. 1987. Evaluation of a clinical preceptor program for new graduates - eight years later. Journal of Continuing Education in Nursing, 18(4), 133-136.

Monnig, R.L. 1983. Professional territoriality in nursing. In The Nursing Profession: A time to speak, edited by Chaska, N.L. New York: McGraw-Hill.

Murphy, M., Hamerstad, S. 1981. Preparing a staff nurse for precepting. Nurse Educator, 6(9), 17-20.

Myrick, F. 1988. Preceptorship. Is it the answer to the problems in clinical teaching? Journal of Nursing Education, 27(3), 136-138.

Myrick, F. 1988. Preceptorship: a viable alternative clinical teaching strategy. Journal of Advanced Nursing, 13 (588-591).

Ogier, M.E. 1982. An ideal sister. London: Royal College of Nursing.

Orton, H. 1981. Ward learning climate. London Royal College of Nursing.

Pienme, J., Kramer, W., Tack, B., Evans, J. 1986. Developing the nurse preceptor. Journal of Continuing Education of Nursing. 17(6), 186-189.

Puetz, B. 1988. Learn the ropes from a mentor. Nursing Success today, 2(6), 11-13.

Reilly, D.E., Oerman, M.H. 1983. The clinical field. Its use in nursing education. Norwalk/Connecticut: Appleton-Century-Crofts.

Scheetz, L.J. 1989. Baccalaureate nursing student preceptorship programs and the development of clinical competence. Journal of Nursing Education, 28(1), 29-35.

Shamian, J., Inhaber, R. 1985. The concept an practise of preceptorship in contemporary nursing: A review of pertinent literature. International Journal of Nursing Studies, 22(2), 79-88

Shogan, J., Prior, M., Kolski, B. 1985. A preceptor program: Nurses helping nurses. Journal of Continuing Education in Nursing, 16(14), 139-142.

Spears, M.W. 1986. The benefits of preceptorships. Journal of Nursing Administration, 16(6), 4

Turnbull, E. 1983. Rewards in nursing: The case of nurse preceptors. Journal of Nursing Administration, 13(1), 10-13.

Walters, C.R. 1981. Using staff preceptors in a senior experience. Nursing Outlook, 29(4), 245-247. 